\title{
Identification of activities of the supply chain management of small and medium -sized enterprise meat chicken producers in Pasuruan district, Indonesia
}

\author{
${ }^{1 *}$ Nuriyanto, N., ${ }^{2}$ Santoso, I., ${ }^{3}$ Soemarno, S. and ${ }^{2}$ Lestari, E.R. \\ ${ }^{1}$ Department of Industrial Engineering, Faculty of Technic, Yudharta University, Pasuruan, East Java, \\ Indonesia \\ ${ }^{2}$ Department of Agro Industrial Technology, Faculty of Agricultural Technology, Brawijaya University, \\ Malang, East Java, Indonesia \\ ${ }^{3}$ Department of Soil Science, Faculty of Agricultural, Brawijaya University, Malang, East Java, Indonesia
}

\author{
Article history: \\ Received: 21 April 2020 \\ Received in revised form: 19 \\ May 2020 \\ Accepted: 31 May 2020 \\ Available Online: 16 July \\ 2020
}

Keywords:

Supply chain management,

Distribution,

Domestic meat chicken

DOI:

https://doi.org/10.26656/fr.2017.4(6).182

\begin{abstract}
Meat chicken producers in Pasuruan district, Indonesia are constantly unable to meet the high demands of consumers. This study was aimed to analyze the strengths, weaknesses, opportunities, and threats (SWOT) of the supply chain management activities of small and medium-sized enterprise (SME) meat chicken producers in Pasuruan district and identify the dominant factors. Data from fifty respondents were analyzed with the SWOT analysis and the analytical hierarchy process to determine the dominant factors of the supply chain management activities. The outcome of the study showed that by increasing the number of transportation and machine usage can be the strengthening strategy for continuous system improvement of SME meat chicken producers.
\end{abstract}

\section{Introduction}

Livestock business has a very positive impact on improving the economy and income of rural communities. This condition is shown by many openings of new restaurants and supermarkets, increasing population, increasing public awareness of nutrition fulfilment, increasing community needs at certain times such as birthday parties, wedding parties, the tendency of selling prices high at certain times such as the fasting month, Eid al-Fitr, Christmas and others (Tobing, 2002). The increasing public interest in running broiler farms is very influential in increasing community activities, both in the livestock business sector itself and other sectors outside the chicken farm business, including feed industry, nursery companies and others (Amenuri and Soekarno, 2010).

The growth of the national livestock population of broilers from 2012 to 2016 had increased. This condition proves that the opportunities and potential of broiler farming are prospects to be developed. Bappenas (2016) showed a significant increase in the production of domestic meat chicken in East Java from 2012, totalling 5,685 tons to 36,782 tons in 2016. In Pasuruan District, the population of domestic meat chicken in 2015 was 3,437,791 tails (Pasuruan District Animal Husbandry
Office, 2015). The price of domestic meat chicken in 2017 was IDR 54, 569/kg while the price of broiler chicken. Preliminary survey results in Pasuruan District showed that the price of 60-day-old poultry is IDR $22,000 /$ head, while the price of broiler chicken ranges between IDR 13,900-14,000/head. Kamarudin (2015) stated that the average consumption of animal protein in developed and developing countries was more than 20 $\mathrm{kg} /$ capita per year. The meat consumption of Singapore and Malaysia is an average of $28 \mathrm{~kg}$ and $36 \mathrm{k} \mathrm{g} /$ capita per year respectively while in Indonesia, the average meat consumption is $4.11 \mathrm{~kg} /$ capita per year.

Budiman (2013) stated that supply chain implementation is an important part of improving the ability of business organization competition and this is no different in managing SME chicken farms. The concept of supply chain management (SCM) is the ability to integrate the management of various management functions in an inter-organizational relationship to form an integrated and mutually supportive system concerning both consumers and suppliers (Williamson et al., 2004; Padillah et al., 2016). A supply chain consists of suppliers, manufacturing centers, warehouses, distribution centers, and retail sellers (Lin et al., 2006). It is developed, because of the desire of one or several parties involved both directly 
and indirectly to fulfill the demand demands of consumers and is a unit that needs each other by means of cooperation (Hult et al., 2007).

SCM can also deploy as an integrator between suppliers, companies, distributors, and customers who use certain tools (Childerhouse and Towill, 2002) and must involve the coordination and management of a complex network of development activities. Cahyono et al. (2013) stated that the implementation of supply chain management for the sustainability of the supply of domestic poultry is also very much needed in relation to meeting domestic needs and export opportunities. Efforts that can be taken are designing and making alternatives to minimize time, cost, and maximize the process.

In Pasuruan district, SME chicken farms encounter several problems in meeting consumers needs due to non -integrated SCM of domestic meat chickens. This phenomenon shows the need to identify the SCM activities for proper implementation of an integrated SCM of domestic meat chickens. Thus, this study is aimed to determine the dominant factors from the SWOT analysis of the SCM activities of domestic meat chickens in Pasuruan District.

\section{Materials and methods}

This research was conducted in three sub-districts of Pasuruan District, East Java Province namely Beji, Gempol, Rejoso. Data were collected from fifty respondents consisting of thirty farmers, five collectors, and fifteen SME. Data were analyzed with the SWOT analysis and the Analytical Hierarchy Process was used to identify the dominant factors of the SCM activities of domestic meat chickens.

\section{Results and discussion}

\subsection{SWOT analysis}

The results of the SWOT analysis in this study develop strategies for strength-opportunities (SO), weaknesses-opportunities (WO), strength-threats (ST) and weaknesses-threats (WT). The results of the SWOT matrix analysis in this study are shown in Table 1, while the results of the SWOT quadrant are shown in Figure 1.

Table 1 shows some weaknesses in the SCM of domestic meat chicken identified in the field, namely; 1) lack of knowledge and skills of farmers in handling diseases and cultivation, 2) a limited number of livestock extension workers, 3) transportation facilities and infrastructure are still inadequate, 4) there is no cooperation between employers, government and business support institutions, 5) fast-food restaurants market reliability and 6) increase in demand every year and not met. Strength includes; 1) demand for domestic meat chicken has increased every year, 2) strengthening the image of small-medium-sized chicken cutting as a producer of quality chicken meat in Pasuruan District, 3) domestic meat chicken disease than broilers and 4) active participation from the office livestock in Pasuruan District through intensive guidance in the form of training and counseling in the domestic meat chicken business.

Identification of problems with threats include; 1) increase of supply of cheap and low-quality domestic meat chicken from outside Pasuruan District, 2) input into the core plasma industry business, which makes the people as livestock workers, and 3) poor road infrastructure between districts. Opportunities include; 1) public awareness of healthy food continues to increase, especially domestic meat chicken, 2) accelerated economic development programs, 3) increasing number of restaurants and tourist areas, and 4) fluctuating live chicken prices are opportunities for SME to increase supply by providing stable prices for suppliers with certain criteria.

Figure 1 shows the SWOT analysis results in quadrant 4, so there is a need to emphasize on the ST strategy. For the ST strategy, the best strategy to overcome weaknesses and face existing challenges is 1) Increasing the number of transportation and 2) increasing the use of machines for continuous improvement of the system. While the SO strategy is the best strategy to take advantage of opportunities with the existing strengths which includes: 1) improvement of the quality of domestic meat chicken and 2) increasing the amount of domestic meat chicken production. As for the WT strategy, the best strategy for overcoming threats with existing strengths is 1) conducting discussions with the government to get road improvement solutions and 2) improving the processing technology for broiler chickens. The WO strategy is the best strategy to take advantage of the opportunities in overcoming existing weaknesses: 1) improving the skills of breeders and SME cutting free-range chicken, 2) cooperating with the

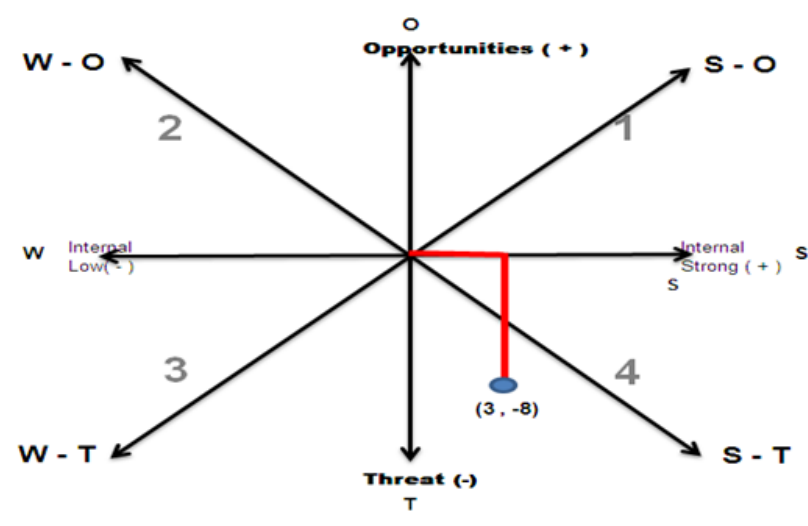

Figure 1. The quadrant of the SWOT analysis results 
Table 1. The SWOT analysis matrix

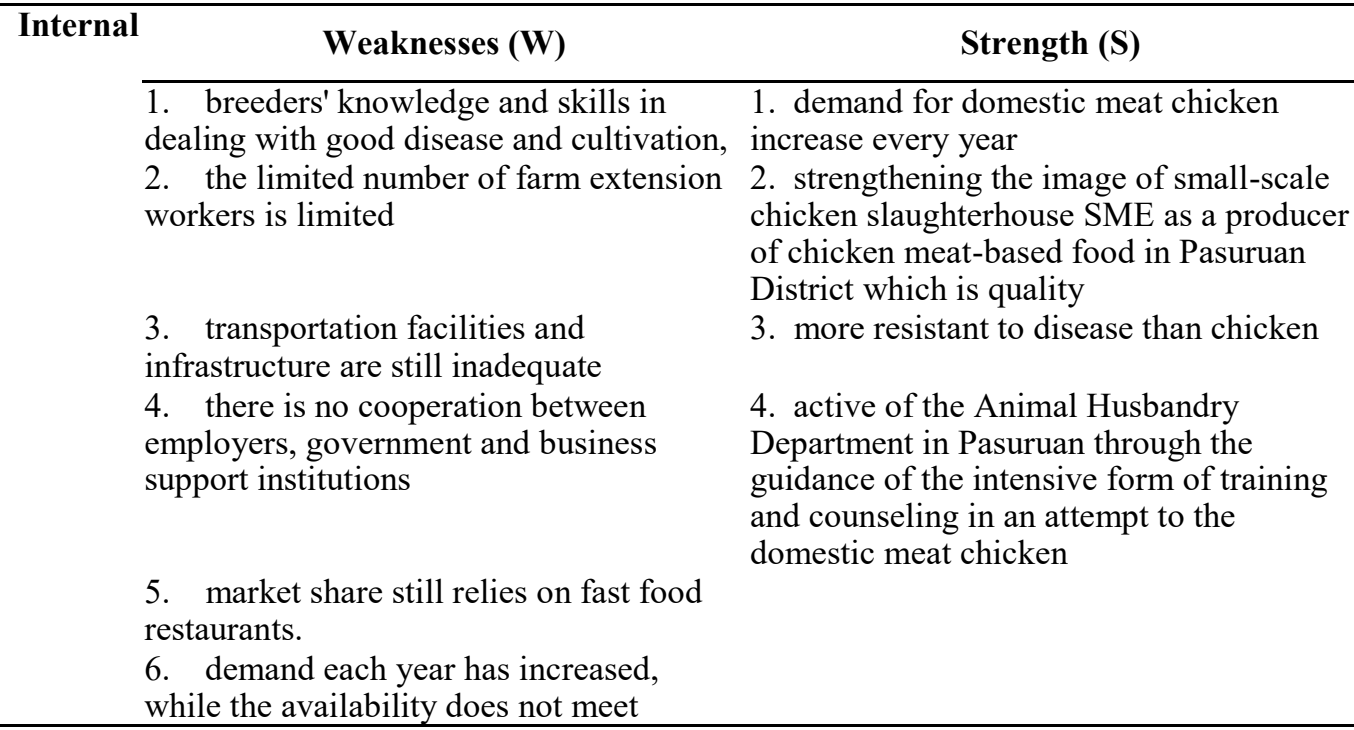

External WO strategy (Overcoming weaknesses SO Strategy (Using the power to take Opportunities (O) to seize opportunities) advantage of opportunities)

1. public awareness of healthy food continues to increase, especially meat of domestic poultry

2. There are programs to accelerate economic development

1. Improving the skills of breeders and 1. Improving the quality of domestic meat SME cutting free-range chicken chicken

2. Doing cooperation with the government and agencies related to transportation facilities

3. increasing number of restaurants, and 3 . Cooperating with the government and
tourist areas

3. increasing number of restaurants, and 3 . Cooperating with the governmer
tourist areas

4. Prices of live chicken fluctuating is an 4. Increasing the market share of opportunity for SME to increase supply by domestic meat chicken providing stable prices for suppliers with certain criteria

\begin{tabular}{|c|c|c|}
\hline Threat (T) & $\begin{array}{l}\text { WT strategy (Overcoming weaknesses } \\
\text { to anticipate threats) }\end{array}$ & $\begin{array}{l}\text { ST Strategy (Using power to overcome } \\
\text { Threats) }\end{array}$ \\
\hline $\begin{array}{l}\text { 1. Increasing supply of domestic meat } \\
\text { chicken cheap, low quality, from outside } \\
\text { Pasuruan District }\end{array}$ & $\begin{array}{l}\text { 1. Conduct discussions with the } \\
\text { government to find road improvement } \\
\text { solutions }\end{array}$ & $\begin{array}{l}\text { 1. Increasing the number of } \\
\text { transportation }\end{array}$ \\
\hline $\begin{array}{l}\text { 2. Enter the plasma core industry } \\
\text { business, which makes people as livestock } \\
\text { workers. } \\
\text { 3. Poor road infrastructure between } \\
\text { districts }\end{array}$ & $\begin{array}{l}\text { 2. Improved cut chicken processing } \\
\text { technology }\end{array}$ & $\begin{array}{l}\text { 2. Increased use of machines to } \\
\text { sustainably improve the system }\end{array}$ \\
\hline
\end{tabular}

government and agencies related to transportation facilities, 3) cooperating with the government and institutions related to the price of chicken, and 4) increasing the market share of domestic meat chicken.

Muhammad and Sumarauw (2014) stated that the addition of workers in the section of chicken meat cutting can minimize the time in supply chain management, while Mongilala (2016) states that the speed of production time will be able to minimize time delays. Nuriyanto et al. (2015) stated that the optimization of order scheduling in the supply chain of free-range chicken showed that the determination of the selling price of free-range chicken played an important role. Simchi-Levi et al. (2000) stated that the objective of supply chain management is to minimize costs throughout the entire system from transportation and distribution to the supply of raw materials, processed goods and finished products, while Padillah et al. (2016) states that integrated inter-organizational integration is very necessary in the supply chain management.

\subsection{Priority analysis of supply chain management activities}

The processing analysis is divided into three levels, namely level 2, 3, and 4. At level 2, horizontal processing is done to the elements objectives to be achieved by SME meat chicken producers in decision making supply chain management. At level 3, factors that influence the making of supply chain management activities while at level 4 is the sub-factors that influence supply chain management activities. This horizontal processing is to see the priority of an element at a level to one level above it. The results of filling out the questionnaire were then processed horizontally using Expert Choice Version 11 software.

3.3 Analytical hierarchy processing - objective elements 
The processing at level 2 in the hierarchical model structure was conducted to determine the priority objectives to be achieved by the SME chicken producer (Table 2). Based on the results of the processing, it can be seen that the main goal to be achieved by SME chicken producer is to maintain the quality of domestic meat chickens $(0.777)$. The next goal to be achieved by SME chicken producer is to get a more efficient distribution line (0.223).

Table 2. Arrangement of weights and priorities of horizontal processing results between elements at level 2

\begin{tabular}{lcc}
\hline \multicolumn{1}{c}{ Objectives } & Weight & Priority \\
\hline $\begin{array}{l}\text { Maintain the quality of domestic meat } \\
\text { chickens }\end{array}$ & 0.777 & 1 \\
$\begin{array}{l}\text { Obtain a more efficient distribution } \\
\text { path }\end{array}$ & 0.223 & 2 \\
\hline Inconsistency ratio & \multicolumn{2}{c}{0.17}
\end{tabular}

The main priority of SME chicken producer is to ensure the products are healthy and environmentalfriendly. This is in accordance with one of the missions which are to research, develop and use technology in production facilities that use local, cheap, healthy and environmental-friendly raw materials. Hence, SME chicken producer should maintain the quality of products, especially in domestic meat chicken as it is one of the superior products.

SME chicken slaughterhouse also needs to evaluate the quality standards of domestic meat chickens every month to measure the quality of free-range meat chickens, whether they are in accordance with established standards. With quality and controlled cultivation process, it is expected to produce good quality domestic meat chicken, as well as the process of mixing domestic poultry and packaging in a chain manufacturer to make a large contribution in determining the quality of domestic poultry produced.

The second priority to be achieved by SME of domestic meat chicken is to get a more efficient distribution channel. This relates to the costs incurred in the shipping process. The domestic meat chicken slaughterhouse SME still uses an old distribution channel. The old distribution channel is a sales fleet and intermediaries which include retailers to distributors (Sukardi 2009). The problem faced in the old distribution channel is the slow distribution of products, there is no promotional media for coordinated programs. From this second priority, obtaining a more efficient distribution channel is the focus of long-term goals for SME cutting domestic meat chicken, while the short-term goal is to maintain the quality of domestic meat chicken.

\subsection{Analytical hierarchy process - between elements of supply chain management activities}

Table 3 tabulates the results of this processing of the outcome of the hierarchical processing at level three to determine the factors that are prioritized in the SCM activities towards each destination. The factors that influence each goal are related factors, whether the supplier, the manufacturer or the distributor.

Based on Table 3, in order to obtain an efficient distribution path, the sales factor ranks first with a weight of 0.423 . With a more efficient distribution channel, SME domestic meat chicken producers expect the sale of domestic meat chicken to increase. Until now, the sales of domestic meat chicken are between close business partners due to high capital turnover, compared to supermarkets. The transport factor ranks second (0.208) from the priority of the supply chain management activities with the aim of obtaining a more efficient distribution path. Transportation factors are considered to directly affect the distribution channels more efficiently because in transportation there are several activities carried out including the selection of roads, means of transportation and directing of shipping to ensure efficiency. Proper transportation is also important to SME domestic meat chicken producer, shipping can be guaranteed on-time.

Table 3. Results of horizontal processing elements of supply chain management activities

\begin{tabular}{|c|c|c|c|c|}
\hline Objectives of & $\begin{array}{c}\text { Factors } \\
\text { Affecting }\end{array}$ & Weight & Priority & $\begin{array}{c}\text { Inconsistency } \\
\text { Ratios }\end{array}$ \\
\hline \multirow{6}{*}{$\begin{array}{l}\text { To Obtain } \\
\text { Efficient } \\
\text { Distribution } \\
\text { Lines }\end{array}$} & Planning & 0.052 & 6 & \multirow{6}{*}{0.11} \\
\hline & Source & 0.075 & 5 & \\
\hline & Making & 0.119 & 4 & \\
\hline & Agents & 0.124 & 3 & \\
\hline & Transportation & 0.208 & 2 & \\
\hline & Sales & 0.423 & 1 & \\
\hline \multirow{6}{*}{$\begin{array}{l}\text { To maintain } \\
\text { the quality of } \\
\text { domestic meat } \\
\text { chicken }\end{array}$} & Planning & 0.058 & 6 & \multirow{6}{*}{0.17} \\
\hline & Source & 0.087 & 5 & \\
\hline & Making & 0.155 & 4 & \\
\hline & Agents & 0.163 & 3 & \\
\hline & Transportation & 0.23 & 2 & \\
\hline & Sales & 0.307 & 1 & \\
\hline
\end{tabular}

The agent factor $(0.124)$ ranks third from the priority of SCM activities with the aim of obtaining a more efficient distribution path. SME chicken slaughterhouse assesses that with the presence of agents (middleman), the distribution channel is a little more efficient than without using an agent. This agent will later distribute the domestic meat chickens to the consumers. Manufacturing activities (0.119) are factors that must be considered in the SCM activities. SME chicken farms 
that avoid using harmful chemical mixtures prove to have more efficient manufacturing activities by time and cost-saving. This is also in line with the mission of SME free-range chicken producer that produce healthy and environmentally friendly products.

The source (0.075), which is the fifth priority of the SCM activities, are the domestic meat chicken farmers. Domestic meat chickens are collected at a place from a variety of chicken farms due to insufficient space in the chicken farms. Therefore, the presence of local chicken producer is efficient. The planning factor ranks sixth or last with a weight of 0.052 . SME free-range chicken producer takes into account everything carefully into planning. When the meeting is conducted to agree on the planning, the planning can be carried out in accordance.

The horizontal processing of the SCM activities of maintaining the quality of domestic meat chickens showed that sales are the top priority with a weight of 0.307. Providing competitive prices in accordance with the quality of domestic meat chickens is one of the sales activities. Prices should be comparable and applicable to the market to garner sales in order to produce a capital turnover to bear for production activities.

The second priority is transportation with the weight of 0.230 . Transportation here is meant by the cleanliness of the transport fleet. It is important to ensure the cleanliness of the products especially livestock as they are perishable items. This is done by ensuring the cleanliness of the transporting fleet. Agent (0.163) ranked third in maintaining the quality of domestic poultry. Agents are required to ensure the domestic meat chickens received from the SME are of high quality before selling it to consumers. When the domestic meat chickens are at the hands of the agent, the agent should maintain the quality of the products. This can be done by ensuring the cleanliness of the chicken storage place and the air circulation at the point of sale.

The manufacturing factor ranks fourth after agent and has a weight of 0.155 . The manufacturing process here is closely related to the process of selecting, cutting, cleaning and packaging. SME domestic meat chicken producers constantly have standards in place by referring to the Indonesian National Standard while SME freerange meat chicken producers might not be up to the standard. Source and manufacturing are both factors that work together. The fifth priority which is source with a weight of 0.087 allows producers to seek high-quality source. This is often observed by the SME domestic meat chicken producers but not in SME free-range meat chicken producers. The planning factor ranks sixth which has a weight of 0.058 . All activities to maintain the quality of domestic poultry are through the planning process. Management should prioritize important activities first to be cost-effective.

3.5 Analytical hierarchy process - between subfactors of the elements of supply chain management activities

At level four of the hierarchy processing, the priority of each subfactor from the third level hierarchy are analyzed (Table 4). The subfactors can be combined subfactors that are linked in with the supplier, manufacturer and distributor. The top subfactor with the weight of 0.527 is measurement/control. Measurement/ control becomes the main benchmark in all activities including planning. The second subfactor with the weight of 0.217 is organization. Human resources should be organized and allocated with sufficient workload. Next, strategy is the third subfactor with the weight of 0.163. A well-plan strategy is required to achieve goals. Finance is the last subfactor with the weight of 0.093 .

The main source factor with a weight of 0.521 is measurement/control. The measurement/control of the

Table 4. Horizontal processing results between subfactor elements for the purpose of obtaining efficient distribution lines.

\begin{tabular}{|c|c|c|c|c|}
\hline Factor & Subfactors & Weight & Priority & $\begin{array}{c}\text { Ratio In } \\
\text { consistency }\end{array}$ \\
\hline \multirow{4}{*}{ Planning } & Financial & 0.093 & 4 & \multirow{25}{*}{0.11} \\
\hline & Strategy & 0.163 & 3 & \\
\hline & Organization & 0.217 & 2 & \\
\hline & Measurement & 0.527 & 1 & \\
\hline \multirow{4}{*}{ Resources } & Financial & 0.099 & 4 & \\
\hline & Technology & 0.121 & 3 & \\
\hline & Organization & 0.259 & 2 & \\
\hline & Measurement & 0.521 & 1 & \\
\hline \multirow{4}{*}{ Preparation } & Strategy & 0.076 & 4 & \\
\hline & Process & 0.168 & 3 & \\
\hline & Organization & 0.269 & 2 & \\
\hline & Risk assessment & 0.487 & 1 & \\
\hline \multirow{4}{*}{ Agent } & Strategy & 0.082 & 4 & \\
\hline & Organization & 0.166 & 3 & \\
\hline & $\begin{array}{l}\text { Inventory } \\
\text { management }\end{array}$ & 0.272 & 2 & \\
\hline & Risk assessment & 0.48 & 1 & \\
\hline \multirow{5}{*}{ Transport } & Strategy & 0.056 & 5 & \\
\hline & Planning & 0.092 & 4 & \\
\hline & $\begin{array}{l}\text { Election of the road } \\
\text { and fare }\end{array}$ & 0,153 & 3 & \\
\hline & Means of transport & 0.258 & 2 & \\
\hline & Evaluate the success & 0.441 & 1 & \\
\hline \multirow{4}{*}{ Sales } & Strategy & 0.088 & 4 & \\
\hline & Organization & 0.127 & 3 & \\
\hline & Process & 0.244 & 2 & \\
\hline & Risk assessment & 0.541 & 1 & \\
\hline
\end{tabular}

source of transportation routes is a benchmark of success of the goal of obtaining an efficient distribution channel. Organization is the second source factor with the weight of 0.259 followed by technology with the weight of 
0.121 and finance with the weight of 0.099 . Organization and control are often in the same cluster whereby to control activities, there should be an organization. Technology should be sourced whenever possible to reduce the usage of manpower to be cost-effective, time save and make the distribution channel more efficient.

Risk assessment is the first priority of manufacturer factor with a weight of 0.487 . After being supervised, the next stage is to assess the risks that will arise as to what of these making factors. It is hoped that by knowing the risks that arise from the factors of manufacture, mitigation of the risk can be carried out. The second priority is organization/human resources with a weight of 0.269 . In this aspect, several things are seen, including the reliability of the interface, the integration of the production system with the entry order system, and the integration of the production system with the customer service system. The process is the third priority of the manufacturing factor with the aim of getting a more efficient distribution path that has a weight of 0.168 . The process of making a simple path is expected to provide a simple distribution path too because domestic meat chickens do not use chemicals so the distribution channel for chemical use becomes nonexistent. Hence, SME domestic meat chicken producers can focus more on the distribution of the final product. The fourth priority is a strategy with a weight of 0.076. In this aspect, an evaluation of the accuracy of the strategies used is carried out, such as making product completion according to the schedule and accuracy of the delivery of raw materials from farmers.

Risk assessment is the first priority of the agent factor with a weight of 0.480 . This sub-factor looks at how much resources are spent in sales activities, the adequacy of information in assessing the resources that come out, and doing an assessment to see if the agent integrates the storage system with the incoming order system or the customer service system. The second priority is the inventory management with a weight of 0.272. This sub-factor looks further at how agents manage their inventory. Organizational or human resource subfactors are the third priority of the agent factor with a weight of 0.166 . This sub-factor is useful to see the state of the organization and human resources contained in the agent. Agents should organize themselves among the SME meat chicken producers. The fourth priority of the agent factor is a strategy with a weight of 0.082 . The strategy relates to the presence or absence of cooperation between agents, the use of shared warehouses.

The first priority of the transportation factor is the evaluation of transportation success with a weight of
0.441 . This subfactor is useful to be able to find out the success of the carrier in the shipping process. Transportation facilities, product shipping documents are the second priority with a weight of 0.258 . In this subfactor, the re-registration procedures of the customer, reduction of goods and facility checking are observed. The third priority is the selection of roads and shipping rates with a weight of 0.153 . In this subfactor, the negotiation process of freight rates, transportation cost, movement of transportation is observed. Planning is the fourth priority of the transportation factor with the aim of achieving a more efficient distribution path with a weight of 0.092 . This is looked at the management of orders. In the last priority is a strategy with a weight of 0.056 . In this sub-factor, the availability of information data on the company activities and the level of success of the transportation system were evaluated.

The risk assessment subfactor becomes the first priority of the sales factor with a weight of 0.541 . In this subfactor, it can be seen whether the sales process is in line with the source, the success rate the existing orders, the sales system meets the market needs and the customer service. The process subfactor is the second priority of the sales factor with a weight of 0.244. Credits, sales forecasting and return goods are observed here. The third priority of the sales factor is the organization/human resources with a weight of 0.127 . This sub-factor looks at whether the organization has sufficient information about the order or needs of its customers. The fourth priority is strategy with a weight of 0.088 . This subfactor strategizing sales to be in line with other company activities. The decision hierarchy model of the SCM activities in SME domestic meat chicken producers along with its weighting in an efficient distribution path is shown in Figure 2.

Peck (2006) stated that an important element of sales in supply chain management is the order fulfillment and on-time delivery. Improvements are needed to address the issues in process control, product distribution, and computerized systems. Fearne et al. (2001) stated that food quality categories are very important to consider because they are related to product appearance, color, health, food safety, certification, product trust and storage and transportation. Mentzer et al. (2001) stated that it is necessary to pay attention to coordination between suppliers and customers to ensure that products are available at the right time and place. Fan et al. (2017) stated that cultural diffusion and the support of supply chain management risk management teams positively influence risk sharing and risk analysis and assessment. The priority risk in the distributor's supply chain greatly influences the competition risk and priority of the retailer supply chain. Therefore, there are six alternative 


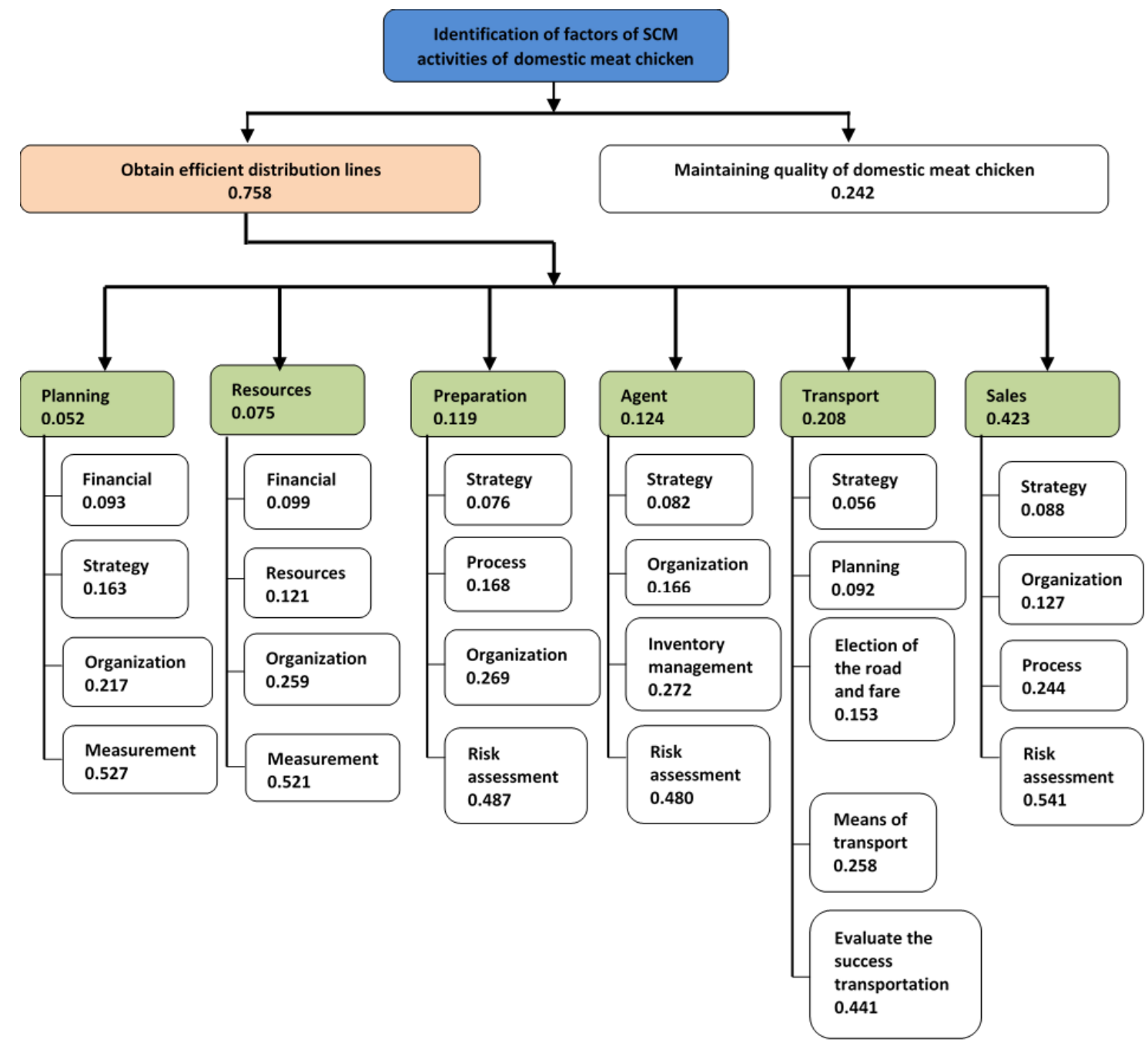

Figure 2. The hierarchy model of SCM activity decisions in SME cutting domestic meat chickens to obtain efficient distribution lines

mitigation strategies, the highest priority risk is selecting the right product followed by maintaining quality, increasing promotion, establishing partnerships, maintaining supply and maintaining price stability (Kurniawan et al., 2019).

\section{Conclusion}

The results of the SWOT analysis indicate the need for emphasis on the ST strategy. The ST strategy, the best strategy to overcome weaknesses and face the challenges that exist is to increase the amount of transportation and increase the use of machines for continuous improvement of the system. Risk assessment factors are the main priority of the goal of obtaining a more efficient distribution channel for SME domestic meat chicken producers.

\section{Conflict of interest}

The authors declare no conflict of interest.

\section{Acknowledgments}

Thanks to the Directorate of Research and Community Service, Directorate General of Research and Development Ministry of Research and the Higher Education Republic of Indonesia, which has provided financial assistance through national research programs.

\section{References}

Amenuri, F.I. and Soekarto, S.T. (2010). Perbandingan sistem usaha mandiri dan plasma pada pembesaran ayam ras pedaging terhadap tingkat pendapatan (studi kasus di Parung). Jurnal Manajemen Pengembangan Industri Kecil Menengah, 1(2), 4457. [In Bahasa Indonesia].

Bappenas. (2016). Produksi daging ayam buras menurut provinsi Tahun 2012-2016. Jakarta, Indonesia: Kementerian PPN/Bappenas. [In Bahasa Indonesia].

Budiman, E.V. (2013). Evaluasi kinerja supply chain pada UD. Maju Jaya di Desa Tiwoho Kabupaten Minahasa Utara. Jurnal Riset Ekonomi, Manajemen, Bisnis dan Akuntansi, 1(4), 443-452. [In Bahasa Indonesia].

Cahyono, W.E., Devianti, I.S. and Supratman, U.W. 
(2013). Analisis dan kajian rantai pasok agribisnis ayam pedaging dengan dea (data envelopment analysis). Jurnal MATRIK, 15, 1 - 9. [In Bahasa Indonesia].

Childerhouse, P. and Towill, D.R. (2002). Analysis of factors affecting real-world value stream performance. International Journal of Production Research, 40(15), 3499-3518. https:// doi.org/10.1080/00207540210152885

Fan, H., Li, G., Sun, H. and Cheng, T.C.E. (2017). An information processing perspective on supply chain risk management: Antecedents, mechanism, and consequences. International Journal of Production Economics, 185, 63-75. https://doi.org/10.1016/ j.ijpe.2016.11.015

Fearne, A., Hornibrook, S. and Dedman, S. (2001). The management of perceived risk in the food supply chain: a comparative study of retailer-led beef quality assurance schemes in Germany and Italy. The International Food and Agribusiness Management Review, 4(1), 19-36. https://doi.org/10.1016/S10967508(01)00068-4

Hult, G.T.M., Ketchen, D.J. and Arrfelt, M. (2007). Strategic supply chain management: Improving performance through a culture of competitiveness and knowledge development. Strategic Management Journal, 28(10), 1035-1052. https://doi.org/10.1002/ smj.627

Kurniawan, M., Santoso, I. and Kamal, M.A. (2019). Risk management of shallot supply chain using failure mode effect analysis and analytic network process (case study in Batu, East Java). IOP Conference Series: Earth and Environmental Science, 230, 012055

Lin, C.T., Chiu, H. and Tseng, Y.H. (2006). Agility evaluation using fuzzy logic. International Journal of Production Economics, 101(2), 353-368. https:// doi.org/10.1016/j.ijpe.2005.01.011

Mentzer, J.T., DeWitt, W., Keebler, J.S., Min, S., Nix, N.W., Smith, C.D. and Zacharia, Z.G. (2001). Defining supply chain management. Journal of Business Logistics, 22(2), 1-25. https:// doi.org/10.1002/j.2158-1592.2001.tb00001.x

Mongilala, G.P. (2016). Koordinasi distribusi rantai pasokan ayam pedaging (studi kasus pada peternakan ayam desa tounelet satu Kecamatan Sonder Kabupaten Minahasa). Jurnal Berkala Ilmiah Efisiensi, 16(4), 794-805. [In Bahasa Indonesia].

Muhammad, M.R. and Sumarauw, J.S. (2014). Evaluasi kinerja manajemen rantai pasok pada pemasok daging ayam, Jeky PM. Jurnal Riset Ekonomi, Manajemen, Bisnis dan Akuntansi, 2(4), 195-202. [In
Bahasa Indonesia].

Nuriyanto, N., Sonief, A.A.A. and Sugiono, S. (2015). Optimasi order schedulling dengan integrasi model evaluasi supply chain. Journal of Engineering and Management in Industrial System, 3(2), 82-86. [In Bahasa Indonesia]. https://doi.org/10.21776/ ub.jemis.2015.003.02.4

Padillah, H., Chrisnanto, Y.H. and Wahana, A. (2016). Model supply chain operation reference (SCOR) dan analytic hierarchy process (AHP) untuk sistem pengukuran kinerja supply chain management. Prosiding SNST Fakultas Teknik, 1(1), 31-36. [In Bahasa Indonesia].

Peck, H. (2006). Reconciling supply chain vulnerability, risk and supply chain management. International Journal of Logistics: Research and Applications, 9 (2), 127-142. https:// doi.org/10.1080/13675560600673578

Simchi-Levi, D., Kaminsky, P. and Simchi-Levi, E. (2000). Designing and managing the supply chain: concepts, strategies and case studies. Singapore: The McGraw-Hill Company, Inc.

Tobing, V. (2002). Beternak ayam broiler bebas antibiotika murah dan bebas residu. Jakarta: Penebar Swadaya. [In Bahasa Indonesia].

Williamson, E., Harrison, D.K. and Jordan, M. (2004). Information systems development within supply chain management. International Journal of Information Management, 24(5), 375-385. https:// doi.org/10.1016/j.ijinfomgt.2004.06.002 